\title{
Once BITten, Forever Shy: Explaining India's Rethink of Its Bilateral Investment Treaty Provisions
}

\author{
Premila Nazareth Satyanand, Independent Researcher
}

\section{Introduction}

On 16 December 2015, the Indian Cabinet approved a new model text for India's bilateral investment treaties (BITs). Over the next few years, India will rely on this text when negotiating, or renegotiating, all bilateral investment agreements and investment chapters in free trade agreements. Significantly, this revised text embodies a fundamental rethink of some of the most hallowed principles underpinning today's international investment agreements (IIA) regime, including the Most Favoured Nation principle and the automatic resort to international arbitration to resolve investor-state disputes. Interestingly, India has narrowed the rights and protections it is willing to offer foreign direct investors when disputes arise, even as it intensifies its effort to attract them.

\section{India: One amongst Many}

As UNCTAD's World Investment Report 2015 (UNCTAD, 2015a) highlights, India is not alone. More and more countries are similarly reconsidering the commitments they are willing to make in their international investment agreements. All are motivated by the same compulsion: to protect themselves against the unforeseen litigatory overreach enabled by some standard IIA provisions. Though such agreements are only signed between states, in practice they give treaty rights to foreign investors, a growing number of which are suing host governments for perceived breaches of treaty provisions.

In fact, this past decade, treaty-based foreign investor arbitrations against host states have tripled, from just over 200 in 2005 to 668 in 2015 (UNCTAD, 2015b), marring the corresponding global surge in foreign direct investment from US\$11 trillion to US\$26 trillion (UNCTAD, 2015a). As a result, many host states are finding themselves constrained from making policy in the best national interest (Basedow, 2015; Hodgson, 2015; Perrone \& de Cerqueira César, 2015; Sauvant \& Ortino, 2013; UNCTAD, 2015a). Moreover, BITs' grant of international arbitration rights to foreign investors renders developing country governments vulnerable to expensive overseas litigation.

Seventy percent of these cases are against developing and transition economies; 80 percent have been filed by developed country investors (UNCTAD, 2015a). Typically, they protest a cancellation or breach of investment contract (29 percent) and the revocation or refusal to grant a license (8 percent). Another major trigger is sudden legislative change (25 percent). Other principal issues include direct expropriation or seizure of investment (15 percent), tax-related complaints (11 percent), and abusive treatment or failure to protect investment (7 percent). A number of cases also relate to judicial acts or omissions, withdrawal of incentives, freezing of bank accounts, sovereign debt restructuring, damage from armed conflict, and interference with management of an investment (UNCTAD, 2015b).

Although 36 percent of the 429 concluded cases ruled in favour of the host country and just 27 percent in favour of the investor (UNCTAD, 2015b), claims and awards are high for developing countries (UNCTAD, 2015a). This is so even in the 26 percent of cases settled through arbitration (UNCTAD, 2015b). This is partly because investors, particularly from industrialized countries, are considerably more fluent and betterresourced in filing international arbitration cases. On average, investors claimed US\$1.1 billion in damages ${ }^{1}$, and tribunals awarded US\$575 million in damages ${ }^{2}$. In 65 cases (15 percent), they claimed well over US\$1 billion, with US\$40 billion being the highest award made thus far (UNCTAD, 2015a).

Claims and awards are also sizeable because cases have tended to concentrate in capital intensive sectors. Two-thirds of the 668 known cases relate to public utilities and services, one-fifth to mining, petroleum and natural gas extraction, and only one-seventh to manufacturing. Power and gas account for the bulk (29 percent) of the service sector claims, followed by financial services (12 percent), telecom ( 8 percent), real estate and civil engineering (both 7 percent). A rash of cases is also seen in water and waste services (both 4 percent), and air transport and warehousing (both 3 percent) (UNCTAD, 2015b).

\section{What Has Triggered India's Rethink?}

A closer look at India's experience explains its move to redraft principal provisions in its model BIT text. Firstly, India has had 16 investor-state dispute cases filed against it since $2000^{3}$. Though this is lower than those against most other global top-ten ISDS respondents, including Canada (Figure 1), India's worry is that the 89 international investment agreements it has signed render it highly vulnerable to expensive litigation (Singh, 2015a), in which disputants can often have an unfair advantage. This is because India's agreements are based on a model text written in 1993, which is no longer in keeping with today's realities.

India first realised this when White Industries Australia (WIAL) won an international arbitration award against Coal India, the country's largest 
Figure 1. Most Frequent Respondent States (total number of known ISDS cases as of end 2014)

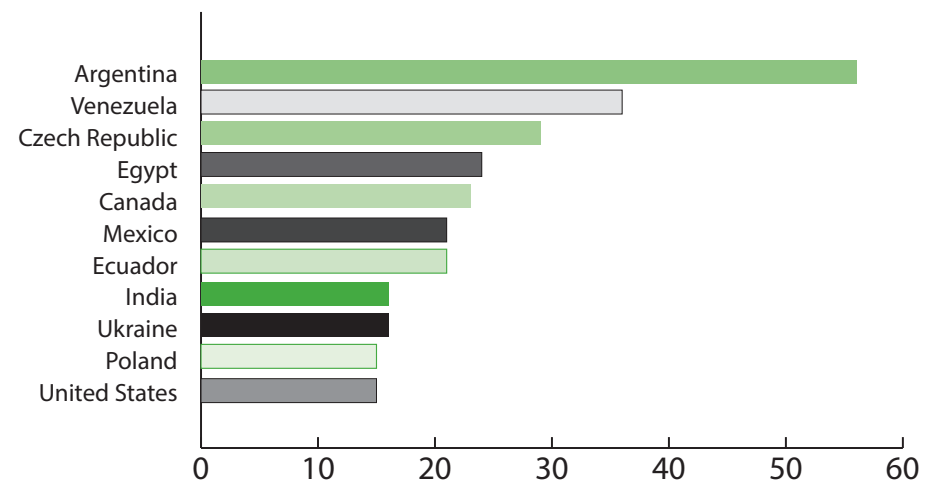

Source: UNCTAD World Investment Report (2015: 115)

public sector miner, in 2012 (Ranjan, 2012). It was the first time that such an award had been issued against India, which had succeeded in settling all nine earlier treaty-based claims against it. ${ }^{4}$

\section{Landmark ISDS Cases in India}

The White Industries Australia versus Coal India Case

In 1989, Coal India contracted White Industries Australia to supply mining machinery and develop a coal mine, and promised to pay approximately A $\$ 206.6$ million (Brower et al., 2011). Once the mine was in operation, a dispute arose between the two entities, with Coal India withholding WIAL's performance bonus and encashing its bank guarantee citing poor production. In 1999, WIAL sought recourse from the International Chamber of Commerce's International Court of Arbitration, which ruled that it was entitled to recover its bonus of $A \$ 2.28$ million and its bank guarantee of $\mathrm{A} \$ 2.77$ million, but it must pay Coal India a penalty of $\mathrm{A} \$ 969,060$ for under-production (Brower et al., 2011).

However, WIAL could not get Coal India to pay due to protracted delays in India's legal process. So, it filed a case under the India-Australia BIT, arguing that India's judicial delay contravened key treaty provisions, including the right to fair and equitable treatment, free transfer of funds, protection against expropriation, and the guarantee of an effective means to enforce rights and assert claims. In keeping with BIT procedure, an international tribunal heard the case and ruled in 2011. It dismissed WIAL's complaints relating to free and equitable treatment, free transfer of funds and expropriation. But it granted WIAL an award of over A\$4 million with interest, and related court fees, conceding that India's failure to enable it to enforce its rights breached this country's BIT obligations to Australia (Brower et al., 2011).

Most pertinently, WIAL won this case by reaching into India's BIT with Kuwait, using the Most Favoured Nation provision in its treaty with Australia (Singh, 2015b). This was because the India-Australia BIT contained no clause guaranteeing investors an effective means of enforcement. But it promised most favoured nation treatment, which it gave Australian investors the right to be treated at par with investors from those countries India had signed similar agreements with. Since the India-Kuwait BIT promised Kuwaiti investors an effective means of asserting claims and enforcing rights with respect to investment, WIAL's lawyers strategically harnessed this clause in WIAL's favour (Singh, 2015b).

\section{The 2G Scam}

A few months later came the collective threat of international litigation stemming from the '2G Scam', in which collusion was discovered in the grant of telecom licenses in 2008. After some years of hearings, in 2012 the Indian Supreme Court canceled 122 of these licenses on grounds of corruption. The most affected foreign firms threatened to invoke India's bilateral investment agreements, if they were not properly and quickly compensated. All argued that the sudden cancellation of these 122 licenses contravened India's BIT commitment to fully protect and not expropriate investments, even though corruption had been established.

\section{The Vodafone Case}

In 2014, when India had already begun to seriously rethink the commitments it was making in its international investment agreements, Vodafone_-its largest telecom investor - filed a treaty-based claim against it. Vodafone, already disputing a US\$3 billion tax claim by the Indian Government, held that India's plan to retrospectively open tax cases was a breach of the country's BIT obligations and a denial of justice (Varman, 2012).

Other global companies similarly engaged in tax disputes with the Indian Government are considering recourse via India's international investment agreements.

\section{The Principal Modifications in India's Model BIT}

The modifications that India has made in its model BIT appear to be intended as much to protect the government's policy space, as to prevent foreign direct investors from "treaty shopping" for favourable provisions that protect them even when at fault. The following sections describe the principal changes.

\section{Treaty Rights and Protections Only for Genuine Foreign Direct Investors}

From now on, India's international investment agreements will benefit only real foreign direct investors that contribute to long-term economic development and fully comply with Indian laws (Singh, 2015c). For this reason, the new model BIT stipulates that India only commits to protecting foreign direct investors with real and substantial business operations in the country, characterized by a large and long-term commitment of capital, the assumption of entrepreneurial risk, a significant number of employees, a noticeable contribution to development, and a transfer of technological knowhow (Government of India, 2015). 
Moreover, only investors with majority control in a locally-invested enterprise, and with direct control in its policy decisions and directorial/ management appointments, will have treaty rights.

In contrast, India's earlier model BIT gave treaty rights to firms with any kind of asset in the country, including moveable and immovable property, shares, debentures, financial contracts, intellectual property rights, and business concessions, even if their business presence was minimal (Singh, 2015c).

\section{Clear Responsibilities for Investors and Their Home States}

After delineating India's duty to protect investors and their investments, India's model text also places responsibilities on both investors and their home states to ensure responsible corporate conduct and inclusive and sustainable growth in its territory (Singh, 2015c). It stipulates, for instance, that "investors and their enterprises operating within its territory of each Party shall endeavour to voluntarily incorporate internationally recognized standards of corporate social responsibility in their practices and internal policies, such as statements of principle that have been endorsed or are supported by the Parties. These principles may address issues such as labour, the environment, human rights, community relations and anti-corruption" (Government of India, 2015). Moreover, "an investor shall provide such information as the Parties may require concerning the investment in question and the corporate history and practices of the investor, for purposes of decision making in relation to that investment or solely for statistical purposes" (Government of India, 2015).

In particular, signatory home states are required to act against investors found to be violating Indian laws.

\section{Elimination of "Most Favoured Nation" Clause}

India's new framework has excised the "Most Favoured Nation" provision, for reasons that the White Industries Australia case makes clear. Though it grants foreign firms treatment on par with domestic ones, it commits to do so only in like circumstances. The new text does away with the 'umbrella clause,' in which the breach of a routine investment contract between an Indian public sector entity and an investor can be considered a violation of a BIT (Singh, 2015c). Also absent is a clause prohibiting India from unilaterally changing laws and regulations that might impact an investment project from the signatory country (Singh, 2015).

\section{International Arbitration Only as the Last Resort}

Disputants must now resolve disputes domestically, resorting to international arbitration only if they can prove they have exhausted all local remedies over a five-year period. This reverses the classic BIT emphasis on guaranteeing immediate international arbitration rights to foreign direct investors. To ensure the impartiality of international tribunals, arbitrators will now be required to abide by strict norms of disclosure and conduct, relating particularly to possible conflicts of interest. At the same time, all documents relating to the dispute are to be shared with the public, who will also have the right to hear tribunal arguments through video links. There are now limits on the international tribunal's power to award monetary compensation.

\section{More Issues Exempted from Treaty Purview}

India has dramatically expanded the list of treaty exemptions beyond the national security exemption permitted by the 1993 model BIT. To start with, foreign firms engaged in a tax dispute with the Indian government cannot employ their home country's BIT to seek legal action. Similarly they cannot invoke treaty rights to block new host country policies/regulations relating to compulsory licensing, state subsidies, government procurement, public health and safety, environmental protection, and financial stability.

\section{Renewable, Ten-Year Life for Each Treaty}

From henceforth, each new BIT will last just ten years, unless specifically extended, and be reviewed every five years. Treaty provisions can also be amended at the request of either party. While, on the one hand, this means that foreign investors' treaty rights might shift as each treaty lapses or is renewed, it also gives them the opportunity to work through their governments to ask for a more favourable revision of particular provisions.

\section{Conclusion}

India's hardened BIT stance seems to contradict its determined push to build global investor confidence and boost inward FDI flows. Well aware of this, the Indian Government is reaching out to other leading FDI home and host economies (including Brazil, South Africa, Canada, Australia, and the United States) to explain its position and explore commonalities. It appears to be encouraged by European countries' wariness of strong ISDS provisions in the investment chapter of the Transatlantic Trade and Investment Partnership (TIPP) agreement, and the widespread resistance to unconditional investor protection from labour unions, environmental groups and civil society in the industrialized world. Significantly, the TIPP has introduced unprecedented provisions to protect states' policy space (Hodgson, 2015), many echoing India's own modifications.

Looking ahead, these IIA-related developments appear to herald a softening of the historical ideological demarcations between industrialized home countries and developing host countries. With 55 percent of yearly global FDI inflows being received by developing countries (UNCTAD, 2015a), many of them, particularly India and China, are of increasing strategic interest to foreign direct investors. Their concerns are thus more likely to be heard internationally. At the same time, since developing countries are now responsible for 35 percent of yearly 
outward global FDI flows (UNCTAD, 2015a), they might be more sympathetic to traditional home country positions.

All this is likely to work to India's advantage, in triggering a more widespread international renegotiation of the legitimate rights and duties of both investors, and their home and host states.

\section{References}

Basedow, R. 2015. Preferential investment liberalization under bilateral investment treaties: How to ensure compliance with WTO law? Columbia FDI Perspectives, 162.

Brower, C. N., Lau, C., \& Rowley, J. W. 2011. Final award in the matter of an UNCITRAL arbitration in Singapore under the agreement between the Government of Australia and the Government of the Republic of India on the promotion and protection of investments between White Industries Australia Limited (Claimant) and the Republic of India (Respondent). London.

Hodgson, M. 2015. The Trans-Pacific Partnership investment chapter sets a new worldwide standard. Columbia FDI Perspectives, 160.

Government of India. 2015. Model Text for the Indian Bilateral Investment Treaty. New Delhi.

Perrone, N. M., \& de Cerqueira César, G. R. 2015. Brazil's bilateral investment treaties: More than a new investment treaty model? Columbia FDI Perspectives, 159.

Ranjan, P. 2012. The White Industries Arbitration: Implications for India's Investment Treaty Program. Investment Treaty News, 13 April.

Sauvant, K. P., \& Ortino, F. 2013. Improving the International Investment Law and Policy Regime: Options for the Future. Helsinki: Ministry for Foreign Affairs of Finland.

Singh, K. 2015a. India and bilateral investment treaties - are they worth it? Financial Times, London.

Singh, K. 2015b. Treaties that gave away the store. The Hindu, Chennai.

Singh, K. 2015c. Decoding India's New Model BIT, New Delhi: Madhyam.

UNCTAD. 2015a. World Investment Report 2015: Reforming International Investment Governance. New York and Geneva: United Nations Conference on Trade and Development.

UNCTAD. 2015b. Investment Dispute Settlement Negotiator. (Web portal). Accessed on 22 December 2015 from http://investmentpolicyhub.unctad.org/ISDS.

UNCTAD. 2015c. UNCTADStat. (Web portal). Accessed on 22 December 2015 from http://unctadstat.unctad.org/wds/TableViewer/ tableView.aspx.

Varman, R. 2012. What's really at stake in the Vodafone tax case? Infochange News and Features, Pune.

\section{Endnotes}

1 This is for the 447 cases for which UNCTAD has the necessary data.

2 This is for the 106 cases for which UNCTAD has the necessary data

3 Nine of the cases against India relate to Enron's ill-fated Dabhol project in Maharashtra, five from the telecommunications-related events discussed in this article, one to coal, and one to ports.

4 All these cases related to Enron's Dabhol power project of the early 1990 s.

Premila Nazareth Satyanand (premila@foreigndirectinvestment. in) is an independent researcher specializing on issues of foreign direct investment. She has worked with the United Nations Centre on Transnational Corporations, New York, and the Economist Intelligence Unit, New Delhi, facilitating the Government-MNC dialogue on FDI liberalisation and advising foreign investors on India strategy. She has consulted for UNCTAD, UNDP, and the World Bank Group. Most recently, she conceived and spearheaded a National Council of Applied Economic Research, New Delhi, project on Indian FDI statistics reform. 